I. Є. Іншакова

\title{
СТРУКТУРНІ ОСОБЛИВОСТІ СЛОВОТВІРНИХ ГНІЗД ІЗ ОДОРАТИВНИМИ КОРЕНЯМИ В УКРАЇНСЬКІЙ МОВІ ІІ ПОЛ. ХІХ СТОЛІТТЯ (ЗА «СЛОВНИКОМ УКРАЇНСЬКОЇ МОВИ» Б. ГРІНЧЕНКА)
}

Іншакова I. Є. Структурні особливості словотвірних гнізд із одоративними коренями в українській мові II пол. ХІХ століття (за «Словником української мови» Б. Грінченка).

Дослідження історії лексичного складу української мови неможливе без 3'ясування історії окремих семантичних груп. Аналіз словотвірних гнізд із одоративними коренями (за словником Б. Грінченка) репрезентує лексику запаху в українській мові II пол. XIX ст.

Ключові слова: запах, одоративна лексика, словотвірне гніздо, похідні, корінь.

Иншакова И. Е. Структурные особенности словообразовательных гнезд с одоративными корнями в украинском языке II пол. ХІХ столетия (по «Словарю украинского языка» Б. Гринченко).

Исследование истории лексического состава украинского языка невозможно без выяснения истории отдельных семантических групп. Анализ словообразовательных гнезд с одоративными корнями (по словарю Б. Гринченко) представляет лексику запаха в украинском языке II пол. XIX ст.

Ключевые слова: запах, одоративная лексика, словообразовательное гнездо, производные, корень.

Inshakova I. Y. Structural features of word-formation nests with odourativnymi roots in Ukrainian II halves XIX century (on «Dictionary of Ukrainian» B. Grinchenko).

Research of history of leksicheskeogo composition of Ukrainian is impossible without finding out of history of separate semantic grup. The analysis of word-formation nests with odorativnymi roots (on a dictionary B. Grinchenko) presents the vocabulary of odour in Ukrainian II halves of XIX of century.

Key words: odour, odourative vocabulary, word-formation nest, derivatives, root. 
Серйозні дослідження в галузі історичної лексикології знайшли відображення в дисертаціях, авторефератах, лексикологічних збірниках, у досягненнях східнослов'янської лексикографії, науковій періодиці, виданнях українських пам'яток. Вивчення окремих семантичних груп словникового складу мови $\epsilon$ традиційним в українському мовознавстві. Ідея системності лексики отримала загальне визнання та знайшла своє втілення в дослідженнях українських учених. Проте до сьогодні, на жаль, не було спроб комплексного опису історії одоративної лексики української мови. Повне ж дослідження історії лексичного складу української мови неможливе без з'ясування історії окремих семантичних груп.

На позначення запахових вражень мова має небагато слів. На цьому наголошував ще I. Я. Франко у праці «Із секретів поетичної творчості»: «Наша мова найбагатша на означення зору, менше багата, але все-таки досить багата на означення вражень слуху і дотику, а найбідніша на означення смаку і запаху» [4, с. 79].

Відомі окремі праці, присвячені частковим аспектам опису лексики на позначення запаху в українській, російській лінгвістиці, психолінгвістиці (І. Я. Франко, О. І. Білецький, В. В. Виноградов, В. П. Сидельников, Л. Вейсгербер, В. Дорошевський, Л. М. Васильєв, Ю. Н. Караулов, А. П. Василевич, Е. В. Гейко, Л. Б. Крюкова, В. В. Лещенко, Н. С. Павлова, І. Г. Рузін, Р. М. Фрумкіна, А. Вежбицька, А. В. Житков, Н. А. Ніколіна та ін.).

Мета нашої статті - аналіз словотвірних гнізд із одоративними коренями в українській мові II пол. XIX ст. Це слова різних граматичних категорій, що містять значення запаху (іменники, дієслова, прикметники, прислівники).

В. Дятчук, Л. Пустовіт у роботі «Семантична структура i функціонування лексики української літературної мови» за основу розподілу слів на позначення запаху взяли морфологічний критерій. Кожна частина мови, як правило, утворює свій семантичний ряд. Серед лексико-семантичної групи одоративів наявні спільнокореневі, які розрізняються продуктивністю словотворення, слововживання. Вважаємо доречним проаналізувати дібрані похідні за словотвірними гніздами.

Найбільшу кількість лексем об'єднує словотвірне гніздо 3 коренем кур- (близько 30 похідних). Переважно це дієслова 3 різноманітними префіксами й відповідні зворотні дієслова: курити (Гр II, с. 329), куритися (Гр II, с. 329), закурювати (Гр II, с. 56), 
закурюватися (Гр II, с. 56), закуріти (Гр II, с. 56), викурювати (Гр I, с. 166), накурювати (Гр II, с. 497), накуритися (Гр II, с. 497), обкурити (Гр III, с. 13), обкурювати (Гр III, с. 13), обкурюватися (Гр III, с. 13), окурити (Гр III, с. 51), підкурювати (Гр III, с. 169), подокурювати (Гр III, с. 255), покурити (Гр III, с. 280), понакурювати (Гр III, с. 305), пообкурювати (Гр III, с. 315), попідкурювати (Гр III, с. 320), розкурювати (Гр IV, с. 70), укуріти (Гр IV, с. 332), укурювати (Гр IV, с. 332), укурюватися (Гр IV, с. 332). Похідних іменників небагато, вони переважно є суфіксальними: курево «дим» (Гр II, с. 329), курещь (Гр II, с. 329), куричка «цигарка» (Гр II, с. 329), курище «1) хмара диму, пилу; 2) вогнище, яке димиться» (Гр II, с. 329), куріння (Гр II, с. 330), виявлено одиничне безафіксне утворення - окур «1) окурювання: початковий легкий вогонь, при якому обпалюване окурюється димом; 2) курево, яким підкурюють бджіл» (Гр ІІІ, с. 51), трапляються поодинокі прикметник - курний «1) що дає багато диму; 2) димний» (Гр II, с. 330), прислівник - курно «димно» (Гр II, с. 330).

Словотвірне гніздо із коренем нюх- (25 дериватів) складається переважно 3 похідних (префіксальних, постфіксальних) дієслів: нюхати (Гр II, с. 573), винюхувати (Гр I, с. 174), донюхуватися (Гр I, с. 421), знюхати (Гр II, с. 176), знюхатися (Гр II, с. 176), нанюхати (Гр II, с. 505), нанюхатися (Гр II, с. 505), нюхнути (Гр II, с. 573), обнюхати (Гр III, с. 21), обнюхувати (Гр III, с. 21), повинюхувати (Гр III, с. 215), подонюхувати (Гр III, с. 244), понюхати (Гр III, с. 313), пообнюхувати (Гр III, с. 316), поперенюхувати (Гр III, с. 324), пронюхати (Гр III, с. 474), рознюхати (Гр IV, с. 53); незначна кількість суфіксальних, безафіксних іменників: нюх (Гр II, с. 573), нюхання (Гр II, с. 573), нюхар «той, хто нюхає тютюн» (Гр II, с. 573), синонім до нього нюхач (Гр II, с. 573), понюх «пучка тютюну» (Гр III, с. 313).

Із чергуванням приголосних зафіксовані дієслова нюшити «нюхати повітря (про тварину)» (Гр II, с. 573), синонім нюшкувати (Гр II, с. 573), понюшити «про тварину: понюхати повітря» (Гр III, с. 313), іменник понюшка = понюх (Гр III, с. 313).

Розмаїтішим на частини мови $є$ словотвірне гніздо 3 коренем пах-. Похідних дієслів з префіксами, постфіксами виявлено не так багато (10): випахатися (Гр I, с. 175), запахнути (Гр II, с. 77), напахати «накурити чимось благовонним, надушити» (Гр II, с. 507), напахатися «напахуватися» (Гр II, с. 507), пахнути (Гр III, с. 103), 
пахтіти «пахнути» (Гр III, с. 103), пахторити = нюшкувати (Гр III, с. 103), пропахати «наситити запахом, напахувати» (Гр III, с. 475), пропахатися «насититися запахом» (Гр III, с. 475), пахати «нюхати» (Гр III, с. 102).

Похідні іменники переважно суфіксальні: пахання «нюхання» (Гр III, с. 102), пахнота (Гр III, с. 103), пахнячка «вид груші» (Гр III, с. 103), naxomi (Гр III, с. 103), naxyчicms (Гр III, с. 103), пахущикк «рід рослини» (Гр III, с. 103), пахно «запах» (Гр III, с. 103) та безафіксні: запах (Гр II, с. 77), пах «запах» (Гр III, с. 102). Виявлено небагато прикметників: запахущий (Гр II, с. 77), пахнучий (Гр III, с. 103), пахучий (Гр III, с. 103), пахущичй (Гр ІІІ, с. 103).

Чергування приголосних у корені спостерігаємо в дієсловах, прикметниках, прислівниках: запашіти (Гр II, с. 77), пашіти «видавати сильний запах» (Гр III, с. 104), запашний (Гр II, с. 77), пашистий (Гр III, с. 104), запашно (Гр II, с. 77).

Близько 25 похідних об'єднує словотвірне гніздо 3 коренем смерд-/ смород- (сморід-), що передає неприємний запах.

Типовими є дієслівні деривати 3 префіксами та постфіксами: висмердітися (Гр I, с. 187), засмердити (Гр II, с. 98), засмердітися (Гр II, с. 98), насмердіти (Гр II, с. 521), пересмердіти (Гр III, с. 137), посмердіти (Гр III, с. 364), просмердіти (Гр III, с. 480), просмердітися (Гр III, с. 480), просмерднути (Гр III, с. 480), розсмердітися (Гр IV, с. 57), смердіти (Гр IV, с. 156). У частини похідних дієслів у корені відбувається чергування д//дж: позасмерджувати (Гр III, с. 259), понасмерджувати (Гр III, с. 308), присмерджувати «припахувати, трохи воняти» (Гр III, с. 439).

Словник фіксує суфіксальні іменники: смердак «дерево горобина» (Гр IV, с. 156), смердюк «вонючий, вонючка» (Гр IV, с. 156), смердюх «комаха» (Гр IV, с. 156), смердюха «вонючий предмет» (Гр IV, с. 156), смердючка «рослина» (Гр IV, с. 156), (у коренях наявне чергування о//i: сморід (Гр IV, с. 160), смородливість «смердючість» (Гр IV, с. 160), смородь = сморід (Гр IV, с. 160) та прикметники: смердючий (Гр IV, с. 156), смородливий (Гр IV, с. 160).

Деривати 3 коренем дим- (15) складають словотвірне гніздо 3 похідних дієслів: диміти (Гр I, с. 384), димитися (Гр. I, с. 384), димувати (Гр I, с. 384), задимити (Гр II, с. 34), задимлювати (Гр II, с. 34), задимувати (Гр II, с. 34), продимати (Гр III, с. 464), продимляти (Гр III, с. 464), продимлятися (Гр III, с. 464), іменників дим (Гр I, с. 384), подимне - субстантив «подать від диму» 
(Гр III, с. 241), синонім подимщина = подимне (Гр III, с. 241), суфіксальних прикметників димний (Гр I, с. 384), димоватий (Гр I, с. 384), прислівника димно (Гр I, с. 384).

Близько 10 лексем об'єднує словотвірне гніздо з коренем кад-. Це дієслова кадити (Гр II, с. 206), кадитися (Гр II, с. 206), закадити (Гр II, с. 45), покадити (Гр III, с. 269), прокадити (Гр III, с. 467), у похідних наявне чергування д/дж: обкаджувати (Гр III, с. 12), позакаджати «покадити» (Гр III, с. 254). Декілька прикметників, іменників утворені суфіксальним способом: кадильний (Гр ІІ, с. 206), кадний (Гр II, с. 206), кадження (Гр II, с. 206), кадило (Гр II, с. 206).

Із коренем чад- серед дериватів наявні дієслова чадити (Гр IV, с. 443), чадіти (Гр IV, с. 443), почадіти (Гр III, с. 390), причадіти (Гр III, с. 451), зачадити (Гр II, с. 115), зачадіти (Гр II, с. 115), іменник чад (Гр IV, с. 443), прикметник чадний (Гр IV, с. 443), прислівник чадно (Гр IV, с. 443).

Словотвірне гніздо з варіантами кореня дух-/душ- складається лише 3 одного дієслова душіти (Гр I, с. 460), іменників дуx (Гр I, с. 459), духота (Гр I, с. 459), задуха «сильний, задушливий запах; сперте, задушливе повітря» (Гр II, с. 37), запридуха «дуже міцний тютюн» (Гр II, с. 85), душок - зменшена форма від дух (Гр I, с. 461), прикметників духовитий (Гр I, с. 459), задушний (Гр II, с. 37), душистий (Гр I, с. 460).

Похідні $з$ коренями тх-/тхір- утворюють невелике за обсягом гніздо, що складається переважно $з$ дієслів затхнутися (Гр II, с. 111), натхорити (Гр II, с. 529), притхнутися (Гр III, с. 449), тхнути (Гр IV, с. 298), тхорити (Гр IV, с. 299), притхле (Гр III, с. 449), іменника тхніння (Гр IV, с. 298).

За вторинним одоративним значенням, мабуть, слід розглядати похідні із коренем дохл-: дієслова та їх форми здохнути (Гр II, с. 147), дохлий (Гр I, с. 435), здохлий (Гр II, с. 147) та іменники дохлина (Гр I, 435), здохленина «м'ясо дохлої худоби» (Гр II, с. 147), здохлина (Гр II, с. 147), здохляк (Гр II, с. 147), здохлятина (Гр II, с. 147); гни-: гнилий (Гр I, с. 293), загнивати (Гр II, с. 27), загниватися (Гр II, с. 27), загнилий (Гр II, с. 27), загнилість «початок гниття» (Гр II, с. 27).

Словотвірне гніздо із коренем дих- складається 3 похідних дієслів подихати (Гр III, с. 241), придихатися (Гр III, с. 414), продихатися (Гр III, с. 464), іменника надха «відрижка 3 неприємним запахом» (Гр II, c. 487). 
Низка дериватів утворює незначні за обсягом словотвірні гнізда (5-6 лексем). Наприклад, із коренем вон-: воняти (Гр I, с. 253), навоняти (Гр II, с. 472), вонючий (Гр I, с. 253), вонливий (Гр I, с. 253), вонючка (Гр I, с. 253); бзд-: дієслово бздіти (Гр I, с. 54), суфіксальні іменники бздини (Гр I, с. 54), бздун (Гр I, с. 54), бздюха (Гр I, с. 54), безафіксний бздо (Гр I, с. 54); пар-: дієслово парувати «димітися» (Гр III, с. 98), прикметники парний «задушливий» (Гр III, с. 97), спарний «душний» (Гр IV, с. 172), прислівники парно (Гр III, с. 97), спарно (Гр IV, с. 172); перд-: пердіти (Гр III, с. 108), іменники пердіж (Гр III, с. 108), пердун (Гр III, с. 108), зменшені форми пердунець, пердунчик, вигук пердь (Гр III, с. 108); вій-: війнути (Гр I, с. 236), вінути (Гр I, с. 239), відвіювати (Гр I, с. 207), віяти (Гр I, с. 244).

Кілька лексем виявлено із коренями вітр-: вітрити «нюхати повітря (про собаку)» (Гр I, с. 242), заповітрити «завонять» (Гр II, с. 82); смал-: смалятина «запах горілого» (Гр IV, с. 156), шмалятина (Гр IV, с. 505); спек-: спечний «жаркий, задушливий (про день)» (Гр IV, с. 174), спечно (Гр IV, с. 174) (iз чергуванням приголосних к//ч у корені).

Виявлені поодинокі лексеми з одоративним значенням: ропнути «перднути» (Гр IV, с. 65); фуніти «видихатися, втрачати запах, блякнути, в'янути» (Гр IV, с. 380); дієслово підходити має лише одне iз значень у словнику під номером 9 одоративне - підійти димом «побувши в диму, віддавати, пахнути димом»: Жито димом підійшло, як пожежа була, так чоловік дешево продавав (Гр III, с. 184); відгонити «віддавати, припахувати»: Чим наївся, тим $і$ відгонить (Гр I, с. 209); сопух «сморід, випаровування» (Гр IV, с. 168); давучий «задушливий»: давучий чад (Гр I, с. 356); кабака «нюхальний тютюн» (Гр II, с. 202); кушпелити «димити» (Гр II, с. 336); ладанити «курити ладаном» (Гр II, с. 340); мерлятина «специфічний запах тварини: собачий, козлячий» (Гр II, с. 419); миркоти «особливий запах овець» (Гр II, с. 426); напсетити «навоняти (про тварин, людину)» (Гр II, с. 513); напшикати «навоняти» (Гр ІІ, с. 514); пакати «палити» (Гр III, с. 87); палити «курити» (Гр III, с. 89); пирний, пирнячий «пряний» (Гр III, с. 152).

Отже, у XIX ст. зросло вживання одоративної лексики в різних стилях і жанрах, що було ознакою вияву реалізму, який тоді охопив усі види мистецтва. Відсутність спеціальних праць із розглядуваної проблеми зумовила необхідність комплексного опису історії одоративної лексики української мови. Однією із важливих пам'яток 
розглядуваного періоду став «Словник української мови» за редакцією Б. Грінченка. У лексикографічній праці (4 томи) виявлено 222 номени 3 одоративним значенням. За частинами мови це дієслова (125), іменники (63), прикметники (25), прислівники (9). Найбільшу кількість лексем об'єднують словотвірні гнізда з коренями кур-, нюх-, пах-, смерд-. Менш продуктивні корені дим-, кад-, чад-, дух-. Низка дериватів утворює незначні за обсягом словотвірні ряди. У словнику виявлені інші поодинокі лексеми з одоративним значенням.

\section{Література}

1. Белецкий А. И. Избранные статьи по теории литературы / А. И. Белецкий. - М. : Просвещение, 1964. - 478 с.

2. Дятчук В. В. Як передається в мові відчуття запаху / В. В. Дятчук // Культура слова. - К., 1978. - Випуск 15. - С. $35-42$.

3. Словарь української мови / Зібр. ред. журн. «Киевская старина». Упорядкував, 3 дод. власн. матеріалу Б. Грінченко. - К. : Лексикон, 1996. - Т. 1-4.

4. Франко І. Я. Із секретів поетичної творчості / Іван Якович Франко // Зібр. творів : у 50-и т. - К., 1980. - Т. 37. -489 с.

Стаття надійшла до редакції 20.06.2012 p. 